\title{
SiC-BASED NANOCOMPOSITES FOR COATING APPLICATIONS INVOLVING WEAR AND CORROSION RESISTANCE ${ }^{1}$
}

\author{
NANOCOMPÓSITOS À BASE DE SIC PARA APLICAÇÕES EM REVESTIMENTOS \\ ENVOLVENDO RESISTENNCIA AO DESGASTE E A CORROSÃO
}

\section{Daniel Moro Druzian², Vinícius Rodrigues Oviedo², Liana da Silva Fernandes 3 , Cristiano Rodrigo Bohn Rodhen ${ }^{3}$ and William Leonardo da Silva ${ }^{3}$}

\begin{abstract}
Nanocomposites containing $\mathrm{SiC}$ as the nano-reinforcement have been widely used in various fields, such as aerospace, automotive, military, and marine industries. In materials engineering, wear and corrosion are two common problems for several applications. Thus, the effects of adding SiC nanoparticles to composites have been studied to improve their physical-chemical and mechanical properties, such as corrosion and wear resistance. In this context, this paper aims to overview the current investigations on nanocomposites containing $\mathrm{SiC}$ nanoparticles as the reinforcement, and with focus on application as a coating involving wear and corrosion resistance. The research was carried out in the ScienceDirect and Web of Science databases, where the papers were selected using the descriptors 'ceramic reinforcement', 'nanocomposite', 'coating', 'SiC', 'silicon carbide', 'wear resistance', 'corrosion resistance' and 'applications'. From this review, 17 scientific articles were found from 1998 to August-2021 involving the application in wear and corrosion resistance. The studies showed improvement on corrosion and wear resistance with the use of SiC-based nanocomposite coatings. Therefore, the differences in the presented results were due to the size and quantity of SiC nanoparticles used in the nanocomposites, being then, able to be used for material applications involving resistance to wear and corrosion.
\end{abstract}

Keywords: Ceramics, silicon carbide, nanoparticles, composite.

\section{RESUMO}

Os nanocompósitos contendo SiC como nano-reforço têm sido amplamente utilizados em vários campos, como aeroespacial, automotivo e indústrias das áreas militares e marinhas. No projeto e engenharia de materiais, degaste e corrosão são dois problemas em comum para diversas aplicações. Logo, os efeitos de adição de nanopartículas de SiC em compósitos têm sido estudados para melhorar propriedades físico-químicas e mecânicas, como resistência à corrosão e ao desgaste. Neste contexto, este artigo busca apresentar uma revisão da literatura acerca das investigações atuais sobre nanocompósitos contendo nanopartículas de $\mathrm{SiC}$ como reforço e com foco aplicação como revestimento envolvendo resistência ao desgaste e corrosão. A pesquisa foi realizada nas bases de dados ScienceDirect e Web of Science, onde foram selecionados trabalhos cientificos, utilizando os descritores 'ceramic reinforcement', 'nanocomposite', 'coating', 'SiC', 'silicon carbide', 'wear resistance', 'corrosion resistance' e 'applications'. A partir desta revisão, foram encontrados 17 artigos científicos voltados para a aplicação em resistência ao desgaste e à corrosão no periodo de 1998 até Agosto-2021. Os estudos encontrados demonstraram aumento na resistência à corrosão e ao desgaste a partir do uso de revestimentos de nanocompósitos à base de SiC. Por conseguinte, as diferenças

1 Study performed at Nanoscience Graduate Program.

2 Academics of the Nanoscience Graduate Program - Franciscan University. E-mail: daniel.moro.druzian@gmail.com; vinicius.oviedo@ufn.edu.br

3 Contributors. Professors of the Nanoscience Graduate Program - Franciscan University. E-mail: liana@ufn.edu.br; cristianorbr@ufn.edu.br; w.silva@ufn.edu.br 
nos resultados apresentados se deram devido ao tamanho e a quantidade de nanopartículas de SiC utilizados nos nanocompósitos, podendo assim, serem utilizados para aplicações de materiais envolvendo a resistência ao desgaste e à corrosão.

Palavras-chave: Cerâmicas, carbeto de silício, nanopartículas, compósito.

\section{INTRODUCTION}

Wear and corrosion are two common problems regarding materials engineered for several applications. Therefore, these two aspects should be considered when designing materials and, particularly, when engineering ceramics and ceramic-based materials (MEDVEDOVSKI, 2001). Wear happens when two material surfaces are in contact and sliding with each other and this can damage one or both parts, leading to a loss of material (HUTCHINGS; SHIPWAY, 2017). On the other hand, corrosion is a type of material deterioration caused by electrochemical and chemical reactions due to the environmental conditions in which the material is exposed (BALAN, 2018).

Thus, carbides have been used as surface coatings for abrasion resistance, mainly in materials such as white steel and cast iron linked to chromium, due to their hardness, size and distribution, increasing wear resistance (MOSLEH-SHIRAZI; AKHLAGHI; YANG, 2016). In this view, silicon carbide (SiC)-based nanocomposites have been investigated to overcome wear and corrosion resistance problems (SHI et al., 2006), since, SiC acts as a barrier against corrosion due to its chemical inertness and wear by preventing the movement of discrepancies and leading to accumulation in the material's grain boundaries (JUSOH et al., 2018).

It is important to mention that there are many forms of corrosion, shown in Figure 1 (e.g., galvanic corrosion, crevice corrosion, pitting corrosion, etc.) (SHASHIN et al., 2019) and they are usually evaluated through electrochemical techniques such as potentiodynamic polarization and/or electrochemical impedance spectroscopy (EIS). The potentiodynamic polarization is widely used, where an electrical potential range is applied to a test electrode (representing the analyte), which results in a polarization curve and several electrochemical parameters (such as corrosion current density and inhibiting efficiency), as well as corrosion rates in a submitted condition, labeled as Tafel slopes (TELEGDI; SHABAN; VASTAG, 2018). On the other hand, EIS evaluates the polarization resistance (an oxidation resistance of the analyte) that can be further used to indirectly determine the corrosion current density, being also a Tafel slope-based characterization method (ATRENS et al., 2018). Thus, the potentiodynamic polarization is simpler than EIS and it enables localized corrosion detection. 
Figure 1 - Types of corrosion and wear.

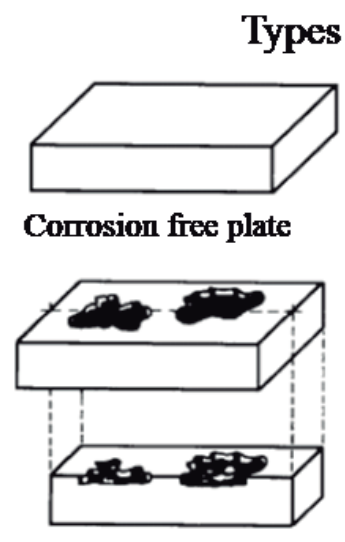

Plaque corrosion
Types of Corrosion

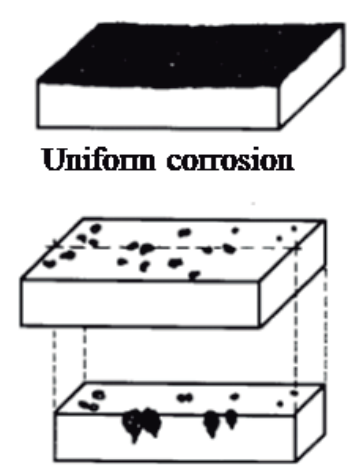

Punctate comosion
Types of Wear

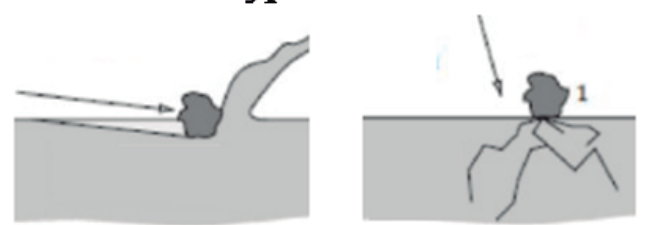

Abrasion wear

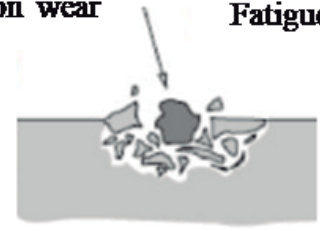

Erosion wear

Source: Adapted from Shashin et al. (2019).

Regarding the wear of the materials, shown in Figure 1, it can be classified mainly as fatigue, friction, erosion, cavitation, adhesion, and abrasive (BAJWA; RAINFORTH; LEE, 2005). In addition, these materials are obtained through dry sliding wear tests, using pin, disk, and ball devices, which can evaluate a wear rate due to the loss of mass of the material using a constant force (ATRENS et al., 2018). The wear resistance of materials is related to the properties of hardness and friction coefficient, that when reduced, leads to a reduced wear resistance (KASIAROVA et al., 2004).

Basically, composites are a class of materials composed of two or more materials (with distinct phases called matrix and reinforcement) in order to obtain a better mechanical and physicochemical performance compared to their counterparts (AMIR et al., 2019; ZHANG et al., 2020). Moreover, when this type of material has one or more dimensions into the nanoscale $(1-100 \mathrm{~nm})$ are labeled nanocomposite, where it is characterized by presenting specific properties (VINYAS el al., 2019) due to the reinforcement phase be in the form of nanoparticles, nanotubes, nanosheets, nanorods, nanowhiskers, nanospheres and/or nanoplatelets (LICCIARDELLO; PIERGIOVANNI, 2020), such as the increase in mechanical strength and biological properties (SERGUEEVA et al., 2009).

In this context, $\mathrm{SiC}$ is a non-oxide ceramic material that has as main features good corrosion resistance, chemical inertness, high thermal, and mechanical stability (ABDERRAZAK; HADJ-HMI, 2011; ERAY, 2020), as well as wear resistance when used as a composite coating (BENEA et al., 2001). The applications of SiC-based nanocomposites involve a several industries (e.g. automotive, aerospace, chemical, petrochemical, electronics) (SHIN et al., 2011; ZENG et al., 2018; LIANG et al., 2020) and these materials have been used such as nanocomposites to increase the wear and corrosion resistance properties. Thus, the present paper aims to show an overview about the current investigations involving SiC-based nanocomposites with focus on wear and corrosion resistance applications during the period of the 1998 - August 2021, using the scientific platforms Science Direct and Web of Science. 


\section{MATERIALS AND METHODS}

The research was carried out using the Science Direct and Web of Science databases from 1998 to 2021 in order to draw a global scenery on the subject of work. The descriptors used were: 'ceramic reinforcement', 'nanocomposite', 'coating', 'SiC', 'silicon carbide', 'wear resistance', 'corrosion resistance', and 'applications'. For the discussion, it was only considered research papers (scientific articles based on the reading of their abstracts) and the exclusion criteria were: (i) papers that did not present $\mathrm{SiC}$ as a composite phase, (ii) papers that did not involve neither wear nor corrosion resistance, and (iii) papers that did not involve any dimension at nanoscale.

\section{RESULTS AND DISCUSSION}

Figure 2 shows the flowchart about bibliographic research during 1998-2021 to Science Direct and Web of Science databases, involving SiC-based nanocomposites applied to corrosion and wear resistance applications over time to both scientific databases, where it was found 17 articles in total concerning the research subjects (using the descriptors 'ceramic reinforcement', 'nanocomposite', 'coating', 'SiC', 'silicon carbide', 'wear resistance ', 'corrosion resistance' and 'applications').

Figure 2 - Flowchart of research and analysis of articles.

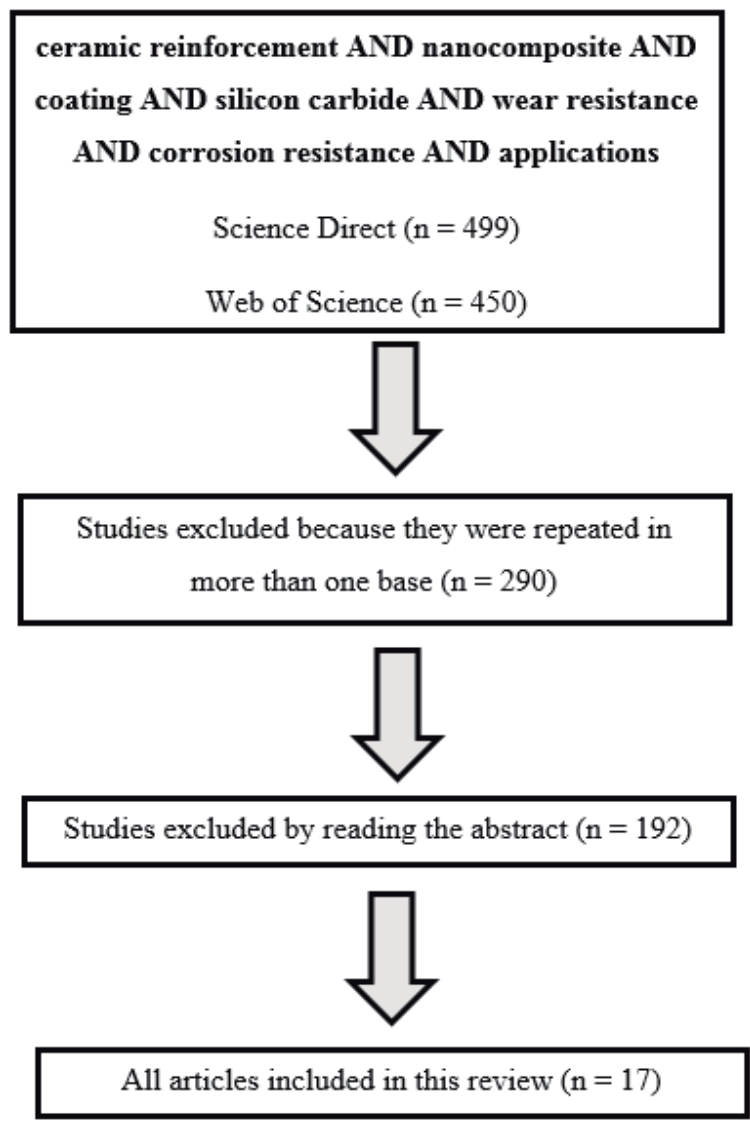

Source: Author's construction. 


\section{CORROSION RESISTANCE}

Table I shows the papers, which investigated SiC-based nanocomposite coatings to get corrosion-resistant materials. Thus, it can be seen the predominance of the electrodeposition method to add the nanocomposites under the substrates. In addition, electrochemical tests (predominantly potentiodynamic polarization) were used to correlate the materials behavior under aggressive electrolyte media with their corrosion resistance. In all these cases, the Tafel slope was a crucial data to infer about the corrosion resistance properties.

Table 1 - SiC-based nanocomposites intended for corrosion resistance applications.

\begin{tabular}{|c|c|c|c|c|c|c|}
\hline Nanocomposite & Substrate & $\begin{array}{c}\text { Coating } \\
\text { addition method }\end{array}$ & Application & $\begin{array}{l}\text { Particle } \\
\text { size }(\mathrm{nm})\end{array}$ & Corrosion evaluation & Reference \\
\hline $\begin{array}{l}\mathrm{Cu} / \mathrm{SiC} \\
\text { coating }\end{array}$ & Pure $\mathrm{Cu}$ & $\begin{array}{c}\text { DC } \\
\text { electrodeposition }\end{array}$ & $\begin{array}{l}\text { Potential fields: boilers, } \\
\text { heat and exchangers }\end{array}$ & 40 & $\begin{array}{c}\text { Potentiodynamic } \\
\text { polarization }\end{array}$ & $\begin{array}{l}\text { MIRSAEED-GHAZI } \\
\text { et al., } 2019 \text { (IF: 4.872) }\end{array}$ \\
\hline $\begin{array}{l}\mathrm{Ni}-\mathrm{SiC} \\
\text { coating }\end{array}$ & $\begin{array}{c}\text { AZ91 } \\
\text { Mg-alloy }\end{array}$ & $\begin{array}{c}\text { DC } \\
\text { electrodeposition }\end{array}$ & $\begin{array}{l}\text { Potential fields: } \\
\text { automotive }\end{array}$ & 40 & $\begin{array}{c}\text { Potentiodynamic } \\
\text { polarization }\end{array}$ & $\begin{array}{c}\text { FINI; AMADEH, } 2013 \\
\text { (IF: } 2.917 \text { ) }\end{array}$ \\
\hline $\begin{array}{l}\mathrm{Ni}-\mathrm{Fe} / \mathrm{SiC} \\
\text { coating }\end{array}$ & Permalloy & Electrodeposition & $\begin{array}{c}\text { MEMs and } \\
\text { mesoscopic systems }\end{array}$ & 50 & $\begin{array}{c}\text { Potentiodynamic } \\
\text { polarization }\end{array}$ & $\begin{array}{l}\text { ATAEE-ESFAHANI } \\
\text { et al., } 2009 \text { (IF: 5.316) }\end{array}$ \\
\hline $\begin{array}{l}\mathrm{NiP} / \mathrm{SiC} \\
\text { coating }\end{array}$ & $\begin{array}{l}\text { Low-carbon } \\
\text { steel plate }\end{array}$ & Electrodeposition & Not specified & $50-100$ & $\begin{array}{c}\text { Potentiodynamic } \\
\text { polarization }\end{array}$ & $\begin{array}{l}\text { AHMADKHANIHA } \\
\text { et al., } 2020 \text { (IF: 2.881) }\end{array}$ \\
\hline $\begin{array}{l}\text { Ni-P-SiC } \\
\text { coating }\end{array}$ & 45 Steel & $\begin{array}{c}\text { Scanning } \\
\text { electrodeposition }\end{array}$ & $\begin{array}{c}\text { Equipment } \\
\text { parts (design) }\end{array}$ & 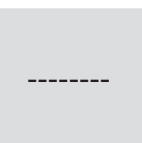 & $\begin{array}{c}\text { Potentiodynamic polarization, } \\
\text { electrochemical impedance } \\
\text { espectroscopy (EIS) }\end{array}$ & $\begin{array}{c}\text { FU et al., } 2020 \\
\text { (IF: } 2.881)\end{array}$ \\
\hline $\begin{array}{l}\mathrm{CeO}_{2}-\mathrm{SiC} \\
\text { coating }\end{array}$ & $\begin{array}{l}\text { Al5083 } \\
\text { alloy }\end{array}$ & $\begin{array}{c}\text { Friction stirs } \\
\text { processing (FSP) }\end{array}$ & $\begin{array}{l}\text { Potential fields: } \\
\text { automotive and marine }\end{array}$ & $50-80$ & $\begin{array}{l}\text { Potentiodynamic } \\
\text { polarization }\end{array}$ & $\begin{array}{c}\text { AMRA et al., } 2015 \\
\text { (IF: } 1.819)\end{array}$ \\
\hline $\mathrm{Al}_{7} \mathrm{O}_{75}-2 \% \mathrm{SiC}$ & None & $\begin{array}{c}\text { Stir casting } \\
\text { followed by FSP }\end{array}$ & $\begin{array}{l}\text { Potential fields: structural } \\
\text { and automotive }\end{array}$ & $40-80$ & $\begin{array}{c}\text { Potentiodynamic } \\
\text { polarization }\end{array}$ & $\begin{array}{l}\text { KUMAR et al., } 2017 \\
\text { (IF: } 5.01\end{array}$ \\
\hline $\begin{array}{l}\mathrm{r}-\mathrm{Go} / \mathrm{SiC} \mathrm{c} \\
\text { oating }\end{array}$ & Pure Mg & $\begin{array}{c}\text { Addition of } \\
\text { precursors in situ }\end{array}$ & $\begin{array}{l}\text { Structural materials for } \\
\text { brackish environments }\end{array}$ & $30-80$ & $\begin{array}{c}\text { Potentiodynamic } \\
\text { polarization }\end{array}$ & $\begin{array}{c}\text { RAMMASAMY } \\
\text { et al., } 2016 \text { (IF: 6.707) }\end{array}$ \\
\hline $\begin{array}{l}\mathrm{Cu}-\mathrm{P} / \mathrm{SiC} \\
\text { coating }\end{array}$ & $\begin{array}{c}\text { Carbon } \\
\text { steel }\end{array}$ & $\begin{array}{l}\text { Electroless } \\
\text { plating }\end{array}$ & $\begin{array}{l}\text { Potential fields: materials, } \\
\text { mineral and chemical }\end{array}$ & 40 & $\begin{array}{c}\text { Potentiodynamic } \\
\text { polarization }\end{array}$ & $\begin{array}{l}\text { FARAJI et al., } 2015 \\
\text { (IF: } 2.433)\end{array}$ \\
\hline
\end{tabular}

According to the Table 1, SiC-based nanocomposite coatings intended for enhancing the corrosion resistance of metallic substrates are mostly added by electrodeposition methods. For example, $\mathrm{SiC} / \mathrm{Cu}$ nanocomposites were added to pure $\mathrm{Cu}$ substrate, and due to $\mathrm{SiC}$ nanoparticles, the corrosion resistance was 1.4-2.5 times greater than the pure substrate and it increased with increased matrix/ reinforcement volume fraction. This corrosion properties improvement characterized by lesser corrosion current densities and inhibiting efficiency ranging from 30-60\% lied on the ability of the nanocomposite coating to fill surface defects, active corrosion sites, and possible corrosion pits as well as lead to decreased occurrence of anodic and cathodic reactions (MIRSAEED-GHAZI et al., 2019).

In the case of Mg-based alloys, which are highly susceptible to corrosion in aggressive media, $\mathrm{SiC}$ nanoparticles were added to a nickel (Ni) matrix due to both corrosion and wear resistance. In the same study, it was observed that the corrosion current density significantly decreased ( $\sim 17$ times less) 
with the increase of $\mathrm{SiC}$ content in the reinforcement phase, and this also happened with the corrosion potential (maximum increase of a 5-fold magnitude). A reasonable explanation for such results is the protective effect of Ni matrix allied with the SiC anti-corrosive reinforcement that results in qualitatively decreasing the corrosion active areas, changing the path available for corrosion, and reducing the superficial defects enhancing corrosion resistance (FINI; AMADEH, 2013).

SiC-based nanocomposite coatings can also be applied to magnetic alloys. In this sense, $\mathrm{SiC}$ nanoparticles (mass fraction of 2.5\%)-reinforced Ni-Fe coatings were applied to permalloy and the corrosion resistance was evaluated in terms of corrosion potential (1,2 times lesser for the nanocomposite) and (17 times lesser than the control coating). The authors showed that the SiC nanoparticles incorporation gave an inert/protective layer to the alloy and trend to decrease the defects on its surface, enhancing corrosion resistance (ATAEE-ESFAHANI et al., 2009).

Regarding combinations of $\mathrm{NiP} / \mathrm{SiC}$ to form nanocomposite coatings, some care should be taken with thermal treating, as seen on the study of Ahmadkhaniha et al. (2020). Despite the focus of the study was to investigate the structural modifications on the $\beta$-SiC nanoparticles-based nanocomposite coatings, the nanocomposite coating did not affect the corrosion resistance behavior of the resulting material (corrosion potential increased from $0.40 \mathrm{~V}$ to $0.19 \mathrm{~V}$, and the current density decreased from $1.8 \times 10^{-6}$ to $1.2 \times 10^{-6} \mathrm{~A} / \mathrm{cm}^{2}$ ), due to the problem of microstructural changes in NiP matrix under heat treating which leads to micro-cracks formation in NiP coatings.

Without applying heat-treating, $\mathrm{SiC}$ nanoparticle reinforcement-based NiP nanocomposite seems to present corrosion resistance improvement, as shown in Fu et al. (2020). The authors investigated the effect of this nanocomposite on polished and sand-blasted samples. In brief, the study confirmed the better corrosion properties of the nanocomposite coating by the significant decrease in corrosion current density (it decreased about $46 \%$ for polished samples and $36 \%$ for sand-blasted) and the increase on corrosion potential in potentiodynamic polarization (that increasing was $64 \%$ for polished samples and $86 \%$ for sand-blasted samples), which is corroborated by the visual increase of impedance arc radius obtained by EIS. Moreover, it was possible shown that the uniform incorporation of SiC nanoparticles, mainly with a sandblasting pre-treatment served as an inert barrier against corrosion.

In addition to parameters as corrosion potential, the pitting potential can be estimated by potentiodynamic polarization, as made by Amra et al. (2015), which investigated $\mathrm{CeO}_{2}(50 \mathrm{~nm})$ and $\mathrm{SiC}$ $(80 \mathrm{~nm})$ nanoparticles-based nanocomposite to coat an Al5083 aluminum alloy. In this case, there were results were using cerium oxide as the matrix and $\mathrm{SiC}$ as the reinforcement, which showed an increase of the $40 \%$ for corrosion potential and a $10 \%$ for pitting potential. The authors concluded that the cerium oxide acts as a cathodic inhibitor that turns pitting corrosion difficult to aluminum alloys, while the inertness of $\mathrm{SiC}$ enhances the protective role of surface against substrate corrosion. 
Concerning aluminum casted alloys, $\mathrm{SiC}$ can be used to produce a nanocomposite with improved corrosion resistance, such as casted A17075-2\% SiC. By evaluating the nanocomposite electrochemical performance, both corrosion and pitting potential values were lesser than those of A17075 bare material, the corrosion current decreased about 80\%. Furthermore, all the results were ascribed to the FSP method, which not only provided corrosion active area decreasing due SiC inertness, but microstructure changes such as better homogeneous dispersion of $\mathrm{SiC}$ on the nanocomposite, interfacial bonding, and grain size refinement (compared to a SiC microcomposite, the nanocomposite presented an average grain size about 58\% lesser) (KUMAR et al., 2017).

It is also possible to combine different nanostructures to get corrosion-resistant materials. Such combination involving reduced-graphene oxide (r-GO) and SiC nanoparticles-based nanocomposite coated on pure magnesium was investigated in Rammasamy et al. (2016) and the inhibiting efficiency was $85 \%$ for the proposed nanocomposite coating compared to rGO (73\%) and $\mathrm{SiC} \mathrm{(27 \% )} \mathrm{coatings}$ only. Additionally, that investigation used the in situ mixing of precursors to add the coating into the substrate and it concluded that the enhanced corrosion resistance for the r-GO/SiC nanocomposite was due to SiC ability to reduce localized corrosion.

It is also worthy to mention that SiC-based nanocomposite coatings can be produced by electroless methods as in Faraji et al. (2015), which studied the effect on the corrosion resistance after coating a carbon steel with a nanocomposite formed onto a $\mathrm{Cu}-\mathrm{P}$ matrix and $\mathrm{SiC}$ nanoparticles as the reinforcement. Succinctly, the corrosion current density showed a reduction of the $73 \%$ for the nanocomposite coating compared to the bare carbon steel, meanwhile the inhibition efficiency was $74 \%$, indicating significant corrosion resistance improving. Moreover, the great results were due to $\mathrm{SiC}$ nanoparticles that act as a physical/protective layer for the substrate (confirmed by optical microscopies) and whose $\mathrm{SiC}$ particles uniform distribution (averaged size of $80 \mathrm{~nm}$ and 99\% purity) plays a role in providing thermodynamic stability to the resulting material.

As expected, in almost all studies from literature with exception of the use of the nanocomposite coatings improved corrosion resistance based on potentiodynamic polarization characterization results.

\section{WEAR RESISTANCE}

Table 2 presents SiC-reinforced nanocomposite coatings to obtain materials with high wear resistance. The predominance of the electrodeposition method for the synthesis/deposition of nanocomposites stands out. In addition, wear tests (predominantly using $\mathrm{Al}_{2} \mathrm{O}_{3}$ pins and balls) were used to relate the mechanical properties under constant force, highlighting the properties of hardness and friction coefficient, which are directly responsible for the wear rate. 
Table 2 - SiC-based nanocomposites intended for wear resistance applications.

\begin{tabular}{|c|c|c|c|c|c|c|}
\hline Nanocomposite & Substrate & $\begin{array}{c}\text { Coating } \\
\text { addition method }\end{array}$ & Application & $\begin{array}{l}\text { Particle } \\
\text { size (nm) }\end{array}$ & $\begin{array}{l}\text { Wear resistance ( } \mu=\text { coefficient of friction, } \\
\beta=\text { wear rate and } \gamma=\text { hardness) }\end{array}$ & Reference \\
\hline $\begin{array}{l}\mathrm{Al} / \mathrm{SiC} \\
\text { coating }\end{array}$ & Pure Al & $\begin{array}{c}\text { Friction } \\
\text { Processing }\end{array}$ & $\begin{array}{l}\text { Potential fields: } \\
\text { automotive and } \\
\text { aviation }\end{array}$ & 50 & $\begin{array}{l}\mathrm{Al} / \mathrm{SiC} \text { with steel } \mathrm{H}-13 \text { and a pin length } \\
\text { of } 6 \mathrm{~mm}(\mu=0,65-0,75, \beta=0,002-0,005 \\
\qquad(10-30 \mathrm{~N}) \text { and } \gamma=140 \mathrm{HV}) \\
\mathrm{Al} / \mathrm{SiC} \text { with steel } \mathrm{H}-13 \text { and a pin length } \\
\text { of } 3.2 \mathrm{~mm}(\mu=0,8-0,9, \beta=0,0025-0,0075 \\
(10-30 \mathrm{~N}) \text { and } \gamma=155 \mathrm{HV})\end{array}$ & $\begin{array}{l}\text { SAADATMAND } \\
\text { et al., } 2014 \\
\text { (IF: } 1.819 \text { ) }\end{array}$ \\
\hline $\begin{array}{l}\mathrm{Mg} / \mathrm{SiC} \\
\text { coating }\end{array}$ & Pure Mg & $\begin{array}{l}\text { Processing } \\
\text { quasi-static } \\
\text { hot pressing }\end{array}$ & $\begin{array}{l}\text { Potential fields: } \\
\text { automotive and } \\
\text { aerospace }\end{array}$ & 75 & $\begin{array}{c}\text { Substrate } \mathrm{Mg}(\beta=0,04(20 \mathrm{~N}) \text { and } \\
\qquad \begin{array}{c}\gamma=48 \mathrm{HV}) \\
\text { Mg with } 10 \% \mathrm{SiC}(\beta=0,028(20 \mathrm{~N}) \text { and } \\
\gamma=70 \mathrm{HV})\end{array}\end{array}$ & $\begin{array}{l}\text { MAJZOOBI et al., } \\
2018 \text { (IF: } 2.626)\end{array}$ \\
\hline $\begin{array}{l}\mathrm{Cu}-\mathrm{Ni}-\mathrm{W} / \mathrm{SiC} \\
\text { coating }\end{array}$ & $\mathrm{Cu}-\mathrm{Ni}-\mathrm{W}$ & Electrodeposition & $\begin{array}{l}\text { Potential fields: } \\
\text { automotive and } \\
\text { aerospace }\end{array}$ & 15 & $\begin{array}{c}\mathrm{Cu}-\mathrm{Ni}-\mathrm{W}(\beta=0,015-0,020(20 \mathrm{~N}) \text { and } \\
\gamma=450 \mathrm{HV}) \\
\mathrm{Cu}-\mathrm{Ni}-\mathrm{W} 10 \% \mathrm{SiC}(\beta=0,005-0,006(20 \mathrm{~N}) \\
\text { and } \gamma=520 \mathrm{HV})\end{array}$ & $\begin{array}{l}\text { DEHGAHI et al., } \\
2016 \text { (IF: } 3.784)\end{array}$ \\
\hline $\begin{array}{l}\mathrm{Cu}-\mathrm{Ni}-\mathrm{W} / \mathrm{SiC} \\
\text { coating }\end{array}$ & $\mathrm{Cu}-\mathrm{Ni}-\mathrm{W}$ & Electrodeposition & Not specified & 50 & $\begin{array}{c}\text { Cu-Ni-W 0,5\% } \mathrm{SiC}(\mu=0,38 \text { and } \\
\gamma=260 \mathrm{HV}) \\
\mathrm{Cu}-\mathrm{Ni}-\mathrm{W} 5 \% \mathrm{SiC}(\mu=0,16 \text { and } \gamma=340 \mathrm{HV})\end{array}$ & $\begin{array}{l}\text { HASHEMI et al., } \\
2014 \text { (IF: 6.901) }\end{array}$ \\
\hline $\begin{array}{l}\mathrm{Ni} / \mathrm{SiC} \\
\text { coating }\end{array}$ & Pure Ni & Electrodeposition & $\begin{array}{l}\text { Potential fields: } \\
\text { oil and gas }\end{array}$ & $45-200$ & $\begin{array}{l}\text { Ni nano-45SiC }(\beta=0,0004-0,0009(0,1-10 \mathrm{~Hz}) \\
\text { and } \gamma=285 \mathrm{HV}) \\
\text { Ni micro-200SiC }(\beta=0,001-0,0013(0,1-10 \mathrm{~Hz}) \\
\text { and } \gamma=255 \mathrm{HV})\end{array}$ & $\begin{array}{l}\text { LANZUTTI et al., } \\
2019 \text { (IF: 4.872) }\end{array}$ \\
\hline $\begin{array}{l}\mathrm{Ni} / \mathrm{SiC} \\
\text { coating }\end{array}$ & Pure Ni & $\begin{array}{l}\text { Magnetic pulse } \\
\text { electrodeposition }\end{array}$ & $\begin{array}{l}\text { Potential field: } \\
\text { mechanics }\end{array}$ & $30-200$ & $\begin{array}{l}\text { Ni nano-30 } \mathrm{nm} \mathrm{SiC}(\beta=0,037(10 \mathrm{~N}) \text { and } \\
\qquad \begin{array}{c}\gamma=903 \mathrm{HV}) \\
\text { Ni micro-200 } \mathrm{nm} \mathrm{SiC}(\beta=0,076(10 \mathrm{~N}) \text { and } \\
\qquad \gamma=598 \mathrm{HV})\end{array}\end{array}$ & $\begin{array}{l}\text { PEN et al., } 2019 \\
\quad \text { (IF: 4.527) }\end{array}$ \\
\hline $\begin{array}{l}\mathrm{Ni}-\mathrm{Co} / \mathrm{SiC} \\
\text { coating }\end{array}$ & $\mathrm{Ni}-\mathrm{Co}$ & Electrodeposition & Not specified & 50 & $\begin{array}{c}\text { Ni-Co }(\gamma=120 \mathrm{HV}) \\
\text { Ni-Co } 11 \% \operatorname{SiC}(\gamma=200 \mathrm{HV})\end{array}$ & $\begin{array}{l}\text { BAHADORMANESH } \\
\text { et al., } 2011 \text { (IF: } 5.316 \text { ) }\end{array}$ \\
\hline $\begin{array}{l}\mathrm{Ni}-\mathrm{Zn}-\mathrm{P} / \mathrm{SiC} \\
\text { coating }\end{array}$ & Ni-Zn-P & Electrodeposition & Not specified & 50 & $\begin{array}{c}\text { Ni-Zn-P }(\mu=0,53, \beta=0,06(10 \mathrm{~N}) \text { and } \\
\gamma=300 \mathrm{HV}) \\
\text { Ni-Zn-P } 10 \% \operatorname{SiC}(\mu=0,70, \beta=0,025(10 \mathrm{~N}) \\
\text { and } \gamma=460 \mathrm{HV})\end{array}$ & $\begin{array}{l}\text { POULADI et al., } \\
2012 \text { (IF: } 4.158)\end{array}$ \\
\hline
\end{tabular}

Source: Author's construction.

The wear rate of $\mathrm{Al} / \mathrm{SiC}$ with steel $\mathrm{H}-13$ and a pin length of $6 \mathrm{~mm}$ was lower than that of $\mathrm{Al} / \mathrm{SiC}$ with steel $\mathrm{H}-13$ and a pin length of $3.2 \mathrm{~mm}$, about 0.002 to 0.0025 respectively; this is attributed to the values of friction coefficient, hardness, and nanoparticle dispersion in the aluminum matrix. The $\mathrm{Al} / \mathrm{SiC}$ with steel $\mathrm{H}-13$ and a pin length of $6 \mathrm{~mm}$ presented a friction coefficient from 0.8 to 0.65 compared to the $\mathrm{Al} / \mathrm{SiC}$ with steel $\mathrm{H}-13$ and a pin length of $3.2 \mathrm{~mm}$, this friction characteristic is responsible for the shear stresses on the surface of the material (abrasion rate per particulate). It denotes the decrease in abrasion with the increase of $\mathrm{SiC}$ nanoparticles and the increase in the abrasion rate with the increase in the resistance of the abrasion tests, due to the silicon carbide preventing the movement of disagreements (SAADATMAND et al., 2014).

The high wear resistance of magnesium matrix nanocomposites with SiC nanoparticle reinforcement is given by the increase in hardness from 48 to $70 \mathrm{HV}$, as well as the strong bond between 
the nano-reinforcement and the Mg matrix, facilitating the transfer of charges to the hard particles. Furthermore, with the increase of SiC nanoparticles, it results in a decrease in the wear rate from 0.04 to 0.028 , because the nanoparticles agglomerate increasing the mechanical strength (MAJZOOBI et al., 2018).

Regarding the $\mathrm{Cu}-\mathrm{Ni}-\mathrm{W}$ matrix nanocomposites containing 10\% w/w SiC nanoparticles as reinforcement, a significant decrease in the wear rate was obtained from 0.015 to 0.005 , this decrease was due to increase of the $\mathrm{SiC}$ on the microhardness and promoting the development of superficial porosities, due to the effect of 3 mechanisms: (a) Orowan mechanism (scattering strengthening - matrix and reinforcement prevent displacement movement, resulting in displacement accumulations in grain boundaries), (b) matrix mechanisms and microstructure of the particle (matrix deformation is constrained by particle incorporation causing charge to be carried so much by the matrix or hard particle) and (c) Hall-Petch mechanism (associated grain refinement reinforcement to structural refinement due to nucleation of smaller surface grains) (DEHGAHI et al., 2016).

The tribological properties of a $\mathrm{Cu}-\mathrm{Ni}-\mathrm{W} / \mathrm{SiC}$ nanocomposite were determined by the values of friction coefficient and hardness, being respectively $0.5 \% \mathrm{w} / \mathrm{w} \mathrm{SiC}(\mu=0.38$ and $\gamma=260 \mathrm{HV})$ and 5\% $\mathrm{w} / \mathrm{w} \mathrm{SiC}(\mu=0.16$ and $\gamma=340 \mathrm{HV})$. The increase in hardness was a result of grain refinement, an increase in grain boundaries which prevents the movement of disagreements and intrinsic limits. In addition, the decrease in the coefficient of friction and decrease in wear resistance was attributed to excess plastic deformation of the nanocomposite surface generated by the agglomeration of SiC nanoparticles, which are responsible for forming voids on the material surface (HASHEMI et al., 2014).

The nanocomposites containing $\mathrm{Ni}$ and nano $\mathrm{SiC}$ reinforcement showed lower wear rate values from 0.001 to 0.0004 compared to micro $\mathrm{SiC}$, due to the material's hardness properties (255 to $285 \mathrm{HV})$; in the case of the microcomposite, the wear rate is related to the hardening effect combined with the refinement of the grain and the strengthening of the dispersion of the matrix with the reinforcement. The nanocomposite is directly related to the Hall-Patch equation that relates the particle size and grain contour of the material. In addition, the wear behavior of the $\mathrm{Ni} / \mathrm{SiC}$ nanocomposite at high frequency $(10 \mathrm{~Hz})$ showed values similar to that of the microcomposite (LANZUTTI et al., 2019).

The mechanical properties of hardness and wear resistance are presented in the values of micro-reinforcement nanocomposites $(\beta=0.076(10 \mathrm{~N})$ and $\gamma=598 \mathrm{HV})$ and nano-reinforcement $(\beta=$ $0.037(10 \mathrm{~N})$ and $\gamma=903 \mathrm{HV}$ ), these results are attributed to 3 factors; (a) particle size; (b) dispersion in the matrix; and (c) particle structure. Decreasing the particle size results in an increase in both hardness and wear resistance. In addition, the synthesis by magnetic pulse electrodeposition promotes fine, compact, and uniform structures, resulting in increased mechanical properties (PEN et al., 2019).

As shown in Table 2, Ni-Co matrix nanocomposite had a hardness of $120 \mathrm{HV}$. When the SiC nanoparticle reinforcement was added, there was an increase of about the $80 \%$, the wear rate was $15 \%$ lower than without nano-reinforcement, and this is attributed to a set of factors such as: (a) quantity of particles, (b) size of dispersed phases, (c) spacing between particles, (d) particle distribution and 
particle morphology and (e) structure and mechanical characteristics of the matrix, resulting in an increase in the boundary quantities of grains, increasing wear resistance (BAHADORMANESH et al., 2011).

The addition of SiC nanoparticles in the Ni-Zn-P composite promoted an increase in hardness from 300 to $460 \mathrm{HV}$, coefficient of friction ( 0.53 to 0.70 ) and a decrease in wear rate from 0.06 to 0.025 . The result of the wear rate was related to the impediment of the displacement movement of the SiC nanoparticles, resulting in an increase in the unevenness in grain boundaries (POULADI et al., 2012).

As expected, in all studies in this literature review, the use of nanocomposite coatings improved hardness as well as wear resistance based on the results and, in addition to that, it also determined whether there was a relationship of particle size with hardness and resistance to wear properties.

\section{CONCLUSION}

The emerging publications involving nanocomposites and corrosion/wear properties denotes the relevance of this subjects in nanoscience and engineering. Based on the works found in the literature, it is possible to highlight the use of electrodeposition as a main method to obtain nanocomposite coatings using $\mathrm{SiC}$ nanoparticles. Furthermore, it was confirmed that the use of $\mathrm{SiC}$ nanoparticles as a nano-reinforcement significantly increases wear and corrosion resistance, currently mainly as a coating of different surfaces. Then, SiC-based nanocomposites could be used as potential materials in the fields of automotive, aerospace, and military industries to overcome wear and corrosion problems. Moreover, SiC nanoparticles size and distribution form in the nanocomposite directly influence the wear and corrosion resistance properties, being considered important factors when designing corrosion and wear resistant nanomaterials.

\section{ACKNOWLEDGEMENTS}

The authors would like to dedicate the acknowledgements to the Franciscan University for the opportunity to carry out this research, as well as for the available resources and infrastructure offered to us. This study was financed in part by the Coordenação de Aperfeiçoamento de Pessoal de Nível Superior - Brasil (CAPES) -"Finance Code 001"

\section{REFERENCES}

ABDERRAZAK, H.; HADJ-HMI, E.S.B. Silicon Carbide: Synthesis and Properties, in: Properties and Applications of Silicon Carbide. InTech, p. 120-150, 2011.

AHMADKHANIHA, D.; ERIKSSON, F.; ZANELLA, C. Optimizing heat treatment for electroplated nip and NiP/SiC coatings. Coatings, v. 10, p. 1-19, 2020. 
AMIR, S.M.M.; SULTAN, M.T.H.; JAWAID, M.; ARIFFIN, A.H.; MOHD, S.; SALLEH, K.A.M.; ISHAK, M.R.; SHAH, A.U.M. Nondestructive testing method for Kevlar and natural fiber and their hybrid composites. Durability and Life Prediction in Biocomposites, v. 10, p. 367-388, 2019.

AMRA, M.; RANJBAR, K.; DEHMOLAEI, R. Mechanical Properties and Corrosion Behavior of $\mathrm{CeO}_{2}$ and $\mathrm{SiC}$ Incorporated A15083 Alloy Surface Composites. Journal of Materials Engineering and Performance, v. 24, p. 3169-3179, 2015.

ATAEE-ESFAHANI, H.; VAEZI, M.R.; NIKZAD, L.; YAZDANI, B.; SADRNEZHAAD, S.K. Influence of $\mathrm{SiC}$ nanoparticles and saccharin on the structure and properties of electrodeposited $\mathrm{Ni}-\mathrm{Fe} / \mathrm{SiC}$ nanocomposite coatings. Journal of Alloys and Compounds, v. 484, p. 540-544, 2009.

ATRENS, A.; SONG, G.L.; SHI, Z.; SOLTAN, A.; JOHNSTON, S.; Dargusch, M.S. Understanding the corrosion of mg and mg alloys, in: Encyclopedia Interfacial Chemical Surface Science Electrochemical. Elsevier, v. 1, p. 515-534, 2018.

BAHADORMANESH, B.; DOLATI, A.; AHMADI, M.R. Electrodeposition and characterization of $\mathrm{Ni}-\mathrm{Co} / \mathrm{SiC}$ nanocomposite coatings. Journal of Alloys and Compounds, v. 509, p. 9406-9412, 2011.

BAJWA, S.; RAINFORTH, W.M.; LEE, W.E. Sliding wear behaviour of SiC-Al $\mathrm{O}_{3}$ nanocomposites. Wear, v. 259, p. 553-561, 2005.

BALAN, K.P. Corrosion, in: Metall. Fail. Anal. Elsevier, v. 2, p. 155-178, 2018.

BENEA, L.; BONORA, P.L.; BORELLO, A.; MARTELLI, S. Wear corrosion properties of nano-structured SiC-nickel composite coatings obtained by electroplating. Wear, v. 249, p. 995-1003, 2001.

DEHGAHI, S.; AMINI, R.; ALIZADEH, M. Corrosion, passivation and wear behaviors of electrodeposited $\mathrm{Ni}-\mathrm{Al}_{2} \mathrm{O}_{3}-\mathrm{SiC}$ nano-composite coatings. Surface and Coatings Technolology, v. 304, p. 502-511, 2016.

ERAY, S. Application of metal oxides in composites, in: Metal Oxide Powder Technologies. Elsevier, v. 2, p. 101-119, 2020.

FARAJI, S.; FARAJI, A.H.; NOORI, S.R.; ANI, F.N. Investigation on electroless Cu-P-micro/nanoSiC composite coatings. Surface Engineering, v. 31, p. 179-188, 2015. 
FINI, M.H.; AMADEH, A. Improvement of wear and corrosion resistance of AZ91 magnesium alloy by applying Ni-SiC nanocomposite coating via pulse electrodeposition. The Transactions of Nonferrous Metals Society of China, v. 23, p. 2914-2922, 2013.

FU, X.; SHEN, Z.; CHEN, X.; LIN, J.; CAO, H. Influence of element penetration region on adhesion and corrosion performance of Ni-base coatings. Coatings, v. 10, p. 895-908, 2020.

HASHEMI, M.; MIRDAMADI, S.; REZAIE, H.R. Effect of SiC nanoparticles on microstructure and wear behavior of Cu-Ni-W nanocrystalline coating. Electrochimica Acta, v. 138, p. 224-231, 2014.

HUTCHINGS, I.; SHIPWAY, P. Introduction, in: Tribology. Elsevier, v. 1, p. 1-5, 2017.

JUSOH, S.M.; NIK, W.; MANSOR, F.; JARKONI, M.N. Corrosion behavior and resistance parameters of silicon carbide nanocomposite coating on different metals. Journal of Mechanical Engineering and Sciences, v. 12, p. 3288-3301, 2018.

KASIAROVA, M.; RUDNAYOVA, E.; DUSZA, J.; HNATKO, M.; SAJGALIK, P.; MERSTALLINGER, A.; KUZSELLA, L. Some tribological properties of a carbon- derived $\mathrm{Si}_{3} \mathrm{~N}_{4} / \mathrm{SiC}$ nanocomposite. Journal of the European Ceramic Society, v. 24, p. 3431-3435, 2004.

KUMAR, A.; PAL, K.; MULA, S. Simultaneous improvement of mechanical strength, ductility and corrosion resistance of stir cast A17075-2\% SiC micro and nanocomposites by friction stir processing. Journal of Manufacturing Processes, v. 30, p. 1-13, 2017.

LANZUTTI, A.; LEKKA, M.; LEITENBURG, C.D.; FEDRIZZI, L. Effect of pulse current on wear behavior of Ni matrix micro-and nano-SiC composite coatings at room and elevated temperature. Tribology International, v. 132, p. 50-61, 2019.

LIANG, J.; WANG, W.; YANG, W.; ZHANG, Z.; ZHANG, X.; JUNG, Y.; DONG, X. Facile synthesis of ceramic SiC-based nanocomposites and the superior electrochemical lithiation/delithiation performances. Materials Chemistry and Physics, v. 243, p. 122618-122632, 2020.

LICCIARDELLO, F.; PIERGIOVANNI, L. Packaging and food sustainability, in: Interaction of Food Industry and Environment. Elsevier, v. 2, p. 191-222, 2020. 
MAJZOOBI, G.H.; RAHMANI, K.; ATRIAN, A. An Experimental Investigation into Wear Resistance of Mg-SiC Nanocomposite Produced at High Rate of Compaction. Journal of Thermal Stresses, v. 3, p. 2588-2597, 2018.

MEDVEDOVSKI, E. Wear-resistant engineering ceramics. Wear, v. 249, p. 821-828, 2001.

MIRSAEED-GHAZI, S.M.; ALLAHKARAM, S.R.; MOLAEI, A. Development and investigation of $\mathrm{Cu} / \mathrm{SiC}$ nano-composite coatings via various parameters of DC electrodeposition. Tribology International, v. 134, p. 221-231, 2019.

MOSLEH-SHIRAZI, S.; AKHLAGHI, F.; YANG, D.L.I. Effect of SiC content on dry sliding wear, corrosion and corrosive wear of $\mathrm{Al} / \mathrm{SiC}$ nanocomposites. The Transactions of Nonferrous Metals Society of China, v. 26, p. 1801-1808, 2016.

PEN, J.S.; ZHOU, C.; SHI, C.; LIU, L.C. Effect of SiC particle size on structures and properties of Ni-SiC nanocomposites deposited by magnetic pulse electrodeposition technology. Ceramics International, v. 45, p. 20155-20164, 2019.

POULADI, S.; SHARIAT, M.H.; BAHROLOLOOM, M.E. Electrodeposition and characterization of Ni-Zn-P and Ni-Zn-P/nano-SiC coatings. Surface and Coatings Technology, v.213, p. 33-40, 2012.

RAMMASAMY, K.V.; SELVARAJ, N.B.; YANG, T.; PRABAKARAN, B.; JOTHI, S. Electrodeposition of r-GO/SiC nano-composites on Magnesium and its Corrosion Behavior in Aqueous Electrolyte. Applied Surface Science, v. 424, p. 63-71, 2016.

SAADATMAND, M.; MOHANDESI, J.; AGHAZADEH, J. Comparison between wear resistance of functionally graded and homogenous Al-SiC nanocomposite produced by friction stir processing (FSP). Journal of Materials Engineering and Performance, v. 23, p. 736-742, 2014.

SERGUEEVA, A.V.; HULBERT, D.M.; MARA, A.K.; MUKHERJEE, A. Chapter 3: Mechanical properties of nanocomposites materials. Frontiers of Nanoscience, v. 1, p. 127-172, 2009.

SHASHIN, M.; MUNIR, K.; WEN, C.; LI, Y. Magnesium matrix nanocomposites for orthopedic applications: A review from mechanical, corrosion, and biological perspectives. Acta Biomaterialia, v. 96, p. 1-19, 2019. 
SHI, L.; SUN, C.; GAO, P.; ZHOU, F.; LIU, W. Mechanical properties and wear and corrosion resistance of electrodeposited $\mathrm{Ni}-\mathrm{Co} / \mathrm{SiC}$ nanocomposite coating. Applied Surface Science, v. 252, p. 3591-3599, 2006.

SHIN, D.G.; CHO, K.Y.; JIN, E.J.; RIU, D.H. Processes and applications of silicon carbide nanocomposite fibers, in: IOP Conference Series: Materials Science and Engineering. Institute of Physics Publishing, p. 82007-82019, 2011.

TELEGDI, J.; SHABAN, A.; VASTAG, G. Biocorrosion-steel, in: Encyclopedia Interfacial Chemical Surface Science Electrochemical. Elsevier, v. 1, p. 28-42, 2018.

VINYAS, M.; ATHUL, S.J.; HARURSAMPATH, D.; LOJA, M.; NGUYEN-THOI, T. A comprehensive review on analysis of nanocomposites: From manufacturing to properties characterization. Materials Research Express, v. 6, p. 92002-92015, 2019.

ZENG, X.; LIU, W.; XU, B.; SHU, G.; LI, Q. Microstructure and mechanical properties of Al-SiC nanocomposites synthesized by surface-modified aluminium powder. Metals, v. 8, p. 253-272, 2018.

ZHANG, G.; LU, H.; MAMIDWAR, S.; WANG, M. Composites, in: Biomaterials Science. Elsevier, v. 1, p. 415-429, 2020. 